\title{
KECEMASAN IBU YANG MEMILIKI REMAJA PUTRI PENDERITA SKIZOFRENIA
}

\author{
Mai Darni', Sulastri²
}

${ }^{1}$ Fakultas Psikologi Universitas Muhammadiyah Lampung. Email: umizanki@gmail.com

${ }^{2}$ Fakultas Psikologi Universitas Muhammadiyah Lampung. Email: sulastri2270@gmail.com

\section{ABSTRACT: ANXIETY AMONG MOTHERS OF DAUGHTER WITH SCHIZOFRENIA}

Introduction: Schizofrenia is a severe mental dirsorder. Adolescence with schizofrenia can be a tough challanger for the parents. Problems in adolescnece with schizofrenia can be a souce of anxiety especially for mothers.

Purpose: This study aims to describe the anxiety in mothers who have young women who suffer from schizophrenia. The subjects in this study were two mothers who had young teenagers with schizophrenia.

Methods: The location of the research was in the Bandar Lampung region. The study was conducted using qualitative methods with methods of collecting data on interviews, observation and documentation.

Results: Based on the results of data analysis it can be concluded that there is anxiety in both respondents in accompanying their young women. The source of anxiety in the first respondent was anxiety because of the pain suffered by the respondent's child, education, future and additional anxiety and in the second respondent who was the source of anxiety was illness, education being taken by the respondent's daughter, and the future. The first respondent with a source of pain, future anxiety, education and the presence of additional anxiety was sufficient to overcome his anxiety after nearly seven years accompanying his daughter. One of the factors is the condition of her daughter who gradually improved, this can be seen from the daughter of the respondent who has been able to carry out daily activities. The second respondent with a source of pain, education and future anxiety still looks anxious, this can be caused either by the condition of his unstable daughter.

Conclusion: Mothers of adolescence with schizofrenia found to be having anxiety.

\section{Keywords: Anxiety, schizophrenia, adolescents}

Pendahuluan: Skizofrenia merupakan gangguan mental yang berat. Remaja penderita skizofrenia menjadi tantangan besar bagi orang tua. Permasalahan pada remaja skizofrenia dapat menimbulkan kecamasan khususnya kepada ibu sebagai pengasuh utama.

Tujuan: Penelitian ini bertujuan untuk mengetahui gambaran kecemasan pada ibu yang memiliki remaja putri yang menderita skizofrenia.

Metode: Subjek dalam penelitian ini adalah dua orang ibu yang memiliki remaja putrid penderita skizofrenia. Lokasi yang menjadi tempat penelitian adalah di wilayah Bandar Lampung.Penelitian dilakukan dengan menggunakan metode kualitatif dengan metode pengumpulan data wawancara, observasi dan dokumentasi.

Hasil: Berdasarkan hasil analisis data dapat disimpulkan bahwa terdapat kecemasan pada kedua responden dalam mendampingi remaja putri mereka. Sumber kecemasan pada responden pertama adalah kecemasan karena sakit yang di derita anak, pendidikan, masa depan dan kecemasan tambahan dan pada responden kedua yang menjadi sumber kecemasan adalah sakit, pendidikan yang sedang ditempuh putri responden, dan masa depan. Responden pertama dengan sumber kecemasan sakit, masa depan,pendidikan dan adanya kecemasan tambahan cukup mampu mengatasi kecemasannya setelah hampir tujuh tahun mendampingi putrinya. Salah satu yang menjadi faktornya adalah kondisi putrinya yang berangsur membaik, hal ini bisa terlihat dari putri responden yang telah bisa melakukan aktivitas sehari-hari. Responden kedua dengan sumber kecemasan sakit, pendidikan dan masa depan masih terlihat kecemasannya, hal ini bisa disebabkan salah satunya karena kondisi putrinya yang belum stabil.

Simpulan: Ibu yang memiliki anak penderita skizofrenia ditemukan mengalami kecemasan.

\section{Kata Kunci: Kecemasan,skizofrenia, remaja}

\section{PENDAHULUAN}

Kecemasan merupakan sebuah fenomena kognitif, dimana seseorang merasa sesuatu akan terjadi diluar kehendak dan tidak bisa diprediksi. Kecemasan akan diperparah jika, seseorang merasa tidak sanggup menghadapinya karena meragukan kemampuan diri sendiri. Menurut Freud kecemasan 
adalah fungsi ego untuk memperingatkan individu tentang kemungkinan datangnya suatu bahaya sehingga dapat disiapkan reaksi adaptif yang sesuai (Wiramihardja,2007). Kecemasan sebagai keadaan yang emosional yang mempunyai ciri keterangsangan fisiologis, perasaan yang tegang yang tidak menyenangkan dan perasaan aprehensi atau keadaan khawatir yang mengeluhkan bahwa sesuatu yang buruk akan segera terjadi (Nevid,Spencer\& Beverly, 2003).

Kecemasan adalah suatu perasaan takut yang tidak menyenangkan yang disertai dengan meningkatnya ketegangan fisiologis.Dalam teori pembelajaran dianggap sebagai suatu dorongan yang menjadi perantara antara suatu situasi yang mengancam dan perilaku menghindar. Kecemasan dapat diukur dengan self report, dengan mengukur ketegangan fisiologis, dengan mengamati perilaku yang tampak (Davison,2006). Kecemasan adalah gangguan psikologis yang mencakup ketegangan motorik (bergetar, tidak dapat duduk tenang, tidak dapat bersantai), hiperaktivitas (pusing, jantung yang berdetak cepat, dan juga berkeringat) dan harapanharapan dan pikiran-pikiran yang mendalam (King,2010).

Menurut Freud (dalam Wiramihardja, 2015) terdapat tiga jenis kecemasan. Pertama, kecemasan nyata (reality anxiety) adalah keadaan yang tidak menyenangkan yang sumbernya objektif atau nyata, rasa takut akan adanya bahaya nyata yang berasal dari luar. Kedua, kecemasan neurotik (neurotic anxiety) adalah kecemasan yang tidak memperlihatkan sebab dan ciri-ciri yang jelas, rasa takut akan hukuman yang muncul jika suatu instink tidak dapat dikendalikan. Ketiga, kecemasan moral (moral anxiety) adalah rasa takut akan suara hati, akibat adanya keinginan yang tertahan didalam hati nurani.

Kesehatan jiwa merupakan bagian integral dari kesehatan. Kesehatan jiwa menurut Maniger (dalam Wiramihardja,2005) merupakan penyesuaian individu terhadap dunia lingkungannya dan terhadap diri orang lain dengan keefektifan dan kebahagian yang maksimum. Efektivitas dan isi dari cara individu yakni adanya penghormatan terhadap ketaatan atas aturan main yang dilakukan secara menyenangkan. Dalam mental yang sehat harus terdapat kemampuan dalam memelihara dirinya, temperamen, inteligen yang siap pakai, perilaku yang memiliki pertimbangan sosial, adanya disposisi atau kecenderungan merasa bahagia.

Terdapat beberapa bentuk-bentuk gangguan kecemasan, dintaranya adalah gangguan obsesiv konfulsif, yaitu Gangguan kecemasan dimana indvidu memilki pikiran-pikiran yang menimbulkan kecemasan yang tidak akan hilang (obsesi), dan/atau dorongan untuk melakukan perilaku berulang yang seperti ritual untuk mencegah atau menghasilkan situasi serupa dimasa depan (kompulasi). gangguan obsesif kompulsif bukan merupakan satu melainkan dua bentuk gangguan, tetapi karena kedua gangguan ini biasanyanya berkaitan maa sering disebut bersamaan. Ganguan obsesif terjadi bila individu merasa dipaksa untuk berpikir mengenai sesuatu cara terus menerus. Jadi dalam hal ini obsesif bersifat terjadi dipikiran, yaitu individu tidak berdaya untuk melawan arus pikiran yang muncul terus menerus dan berulang-ulang, seolah-olah pikiran tersebut memiliki kekuatan sendiri dan tidak bisa dikendalikan.

Gangguan kompulsif biasanya menyertai gangguan obsesif karena gangguan kompulsif terjadi bila individu dipaksa dengan segera untuk melakukan tindakan tindakan atau tingkah laku tertentu yang sebenarnya tidak diinginkannya, tetapi bila tidak dilakukan muncul perasaan bersalah, cemas, dan sebagainya sehingga akhirnya dia melakukannya (Siswanto,2007)

Ciri-ciri kecemasan menurut Nevid,Spencer \& Beverly (2003) adalah :

1. Secara fisik meliputi kegelisahan, kegugupan, tangan dan anggota tubuh yang bergetar atau gemetar, banyak berkeringat, mulut atau kerongkongan terasa kering, sulit berbicara, sulit bernafas, jantung berdebar keras atau bertak kencang, pusing ,merasa lemas atau mati rasa,sering buang air kecil, merasa sensitif, atau mudah marah.

2. Secara behavioral meliputi perilaku menghindar, perilaku melekat dan dependent, perilaku terguncang.

3. Secara kognitif meliputi khawatir tentang sesuatu, perasaan terganggu atau ketakutan atau aphensi terhadap sesuatu yang terjadi dimasa depan, keyakinan bahwa sesuatu yang mengerikan akan segera terjadi tanpa penjelasan yang jelas, ketakutan akan kehilangan kontrol, ketakutan akan ketidakmampuan untuk mengatasi masalah, berpikir bahwa semuanya tidak bisa lagi dikendalikan, merasa sulit memfokuskan pikiran dan berkonsentrasi.(Nevid,Spencer\& Beverly, 2003).

Mai Darni1Fakultas Psikologi Universitas Muhammadiyah Lampung. Email: umizanki@gmail.com

Sulastri2Fakultas Psikologi Universitas Muhammadiyah Lampung. Email: sulastri2270@gmail.com 
Gangguan jiwa atau yang biasa disebut dengan gangguan mental adalah penyimpangan dari keadaan ideal dari suatu kesehatan mental (Kaplan \& Sadock,1990) atau dapat pula dimaknakan dengan tidak sehatnya mental atau kurangnya kesehatan mental (Notosoedirjo dan Latipun,2005).

Konsep gangguan jiwa dari PPDGJ II yang merujuk ke DSM-III adalah sindrom atau perilaku, atau psikologik seseorang yang secara klinik cukup bermakna, dan yang secara khas berkaitan dengan suatu gejal penderitaan (distress) atau hendaya (impairmen/disability) di dalam satu atau lebih fungsi yang penting dari manusia. Sebagai tambahan, disimpulkan bahwa disfungsi adalah disfungsi dalam segi perilaku, psikologik, atau biologik, dan gangguan itu tidak sema-mata terletak di dalam hubungan antara seorang dengan masyarakat. (Maslim, 2013)

Penyebabnya gangguan jiwa menurut Kartono (2011) adalah a. Faktor organis atau somatis; misalnya terdapat kerusakan pada otak dan proses dementia. B. Faktor-faktor psikis dan struktur kepribadiannya; misalnya reaksi neurotis dan reaksi psikotis pribadi terbelah, pribadi psikopatis dan lainlain. Kecemasan, kesedihan, kesakitan hati, depresi, dan rendah diri bisa menyebabkan orang sakit secara psikis, mengakibatkan ketidakseimbangan mental dan desintegrasi kepribadiannya. Maka struktur kepribadiannya dan pemasakan pengalamanpengalaman dengan cara yang keliru bisa membuat orang tergnggu jiwanya. Terutama sekali apabila beban psikis ternyata jauh lebih berat dan melampaui kesanggupan memikul bebn tersebut. C. Faktor-faktor linkungan atau sosial, faktor-faktor milieu, pergaulan, masyarakat luas.

Perkembangan dunia remaja saat ini membawa remaja berada pada masa rawan, masa badai dan masa stess.Faktor ini salah satunya adalah disebabkan oleh kemajuan ilmu penegetahuan dan teknologi serta arus globalisasi yang begitu kuat, yang memaksa remaja untuk bisa menyesuaikan diri dengan perubahan-perubahan tersebut.Kegagalan dalam melakukan penyesuaian terhadap perubahanperubahan pada akhirnya dapat menimbulkan stressor psikososial bagi remaja, sehingga tidak sedikit remaja yang mengalami gangguan kejiwaan baik ringan maupun berat (Ali dan Asrori,2016).

Gangguan pada masa remaja dan anakanak, yang disebut sebagai childhoot disorders dan menimbulkan penderitaan emosional minor serta gangguan kejiwaan lain pada tingkah lakuny. Dan di kemudian hari bisa berkembang menjadi bentukbentuk kenakalan remaja (Kartono, 2010)

Tugas masa perkembangan masa remaja difokuskan pada upaya meninggalkan sikap dan perilaku kekanak-kanakan serta berusaha untuk mencapai kemampuan bersikap dan berperilaku secara dewasa. Adapun tugas-tugas perkembangan masa remaja (Harlock,1989) adalah sebagai berikut:

1) Mampu menerima keadaan fisiknya

2) Mampu menerima dan memahami peran seks usia dewasa

3) Mampu membina hubungan baik dengan anggota kelompok

4) Mencapai kemandirian emosional

5) Mencapai kemandirian ekonomi

6) Mengembangkan konsep dan ketrampilan sangat diperlukan untuk melakukan peran sebagai anggota masyarakat.

7) Memahami dan menginternalisasikan nilai-nilai orang dewasa dan orang tua

8) Mengembangkan perilaku tanggung jawab sosial yang diperlukan untuk memasuki dunia dewasa.

9) Mempersiapkan diri untuk memasuki perkawinan

10) Memahami dan mempersiapkan berbagai tanggung jawab kehidupan keluarga

Tugas-tugas perkembangan remaja yang amat penting adalah mampu menerima keadaan dirinya. Memahami peran seks/jenis kelamin,mengembangkan

kemandirian,mengembangkan tanggung jawab pribadi dan sosial,menginternalisasikan nilai-nilai moral dan merencanakan masa depan. Dewasa ini tidak sedikit remaja yang melakukan perbuatan antisocial maupun asusila karena tugas-tugas perkembangan tersebut kurang berkembang dengan baik (Sarwono,2012)

Skizofrenia merupakan kelompok gangguan psikosis atau psikotik yang ditandai terutama oleh distorsi-distorsi mengenai realitas, juga sering terlihat adanya perilaku menarik diri dari interaksi sosial, serta disorganisasi dan fragmentasi dalam hal persepsi, pikiran dan kognisi (Carson dan Butcher dalam Wiramihardja 2005).Skizofrenia adalah gangguan mental yang sangat berat.Gangguanini di tandai dengan gejala-gejala positif seperti pembicaraan yang kacau, delusi, halusinasi, gangguan kognitf dan persepsi.Sedangkan gejala negatifnya antara lain seperti avolition (menurunnya minat dan dorongan),

Mai Darni'Fakultas Psikologi Universitas Muhammadiyah Lampung. Email: umizanki@gmail.com

Sulastri2Fakultas Psikologi Universitas Muhammadiyah Lampung. Email: sulastri2270@gmail.com 
berkurangnya keinginan bicara dan miskinnya isi pembicaraan, afek yang datar, serta terganggunya relasi personal.Tampakgejala-gejala skizofrenia menimbulkan hendaya berat dalam kemampuan individu berfikir dan memecahkan masalah, kehidupan afek dan menggangu relasi personal. Semua hal tersebut mengakibatkan individudengan skizofrenia mengalami penurunan fungsi ataupun ketidakmampuan dalam menjalani hidupnya, sangat terhambat produktivitasnya dan nyaris terputus relasinya dengan manusia lain (Setiadi, 2014).

Saddock and Saddock (2001) mengungkapkan bahwa 15 persen penderita yang masuk rumah sakit jiwa adalah pasien skhizofrenia dan sebagian besar pasien ini akan tinggal di rumah sakit untuk jangka waktu yang lama. Pria lebih sering daripada wanita untuk menderita skizofreniadan kebanyakan dimulai sebelum usia 30 tahun. Kasus yang paling sering adalah pada usia 15 tahun sampai 35 tahun (50\% dibawah usia 25 tahun) dan jarang sebelum usia 10 tahun atau sesudah 40 tahun (Saddock and Saddock,2001). Usia puncak onset untuk laki-laki adalah 15 - 25 tahun, sedangkan untuk wanita usia puncak adalah 25 - 35 tahun (Kaplan dan Saddock,1997).

Gangguan skizofrenia dapat terjadi pada setiap individu baik laki-laki maupun perempuan, dari usia anak-anak hingga dewasa. Pada anak-anak gejalagejala skizofrenia tidak nampak jelas, sedangkan pada individu dewasa tampak lebih jelas (Wiramihardja,2005).

Salah satu jenis atau bentuk gangguan jiwa yang dialami oleh anak usia remaja adalah gangguan jiwa skizofrenia. Gangguan ini muncul akibat manifestasi dari berbagai permasalahan dan persaingan hidup seperti tidak bisa menerima kekecewaan, adanya konflik keluarga, ketidaksesuaian antara apa yang diharapkan dengan kenyataan yang diterima ataupun tekanan dari orang tua serta kondisi sosial menyebabkan seorang remaja tidak mampu mengendalikan dirinya.Jika salah satu anggota keluarga memiliki gangguan psikologis, para ahli teori sistem keluarga tidak melihatnya sebagai permasalahan dalam individual, tetapi sebagai suatu indikasi mengenai sistem keluarga yang disfungsional. Bentuk-bentuk khusus yang memungkinkan anggota keluarga mengalami psikopatologi akan tergantung pada interaksi yang kompleks diantara keeratan keluarga (families-cohesiveness), kemampuan untuk berubah dan kemampuan untuk merespon tuntutan lingkungan, serta gaya dan atau teknik berkomunikasi. Suatu keluarga yang tidak fleksibel, resisten dan terisolasi dari semua kekuatan-kekuatan yang ada di luarnya dan tidak dapat menyesuaikan diri dengan baik untuk berubah, sering memperlihatkan dampak negative kepada anggota-anggota keluarga (tertentu) berupa abnormalitas (Wiramihardja,2005).

Gejala-gejala skizofrenia biasanya diklasifikasikan sebagai gejala-gejala positif, gejalagejala negative dan defisit kognitif.

1. Gejala positif

Gejala positif ditandai dengan adanya distorsi atau kelebihan dalam fungsi normal, dan biasa disebut "positif" karena mencerminkan sesuatu yang ditambahkan di atas atau lebih dari perilaku normal. Gejal-gejala positif dari skizofrenia mencakup halusinasi, delusi, pikiran yang terganggu dan gangguan pada pergerakan.

2. Gejala negative

Gejala negative skizofrenia mencerminkan kekurangan perilaku dan hilangnya atau turunnya fungsi normal seseorang. Karenanya gejala positif melibatkan sesuatu yang berlebihan, gejala negative melibatkan ketidakhadiran sesuatu. Satu gejala negative adalah afek datar (flat effect) yang berarti bahwa orang tersebut menunjukkan sedikit atau tidak menunjukkan emosi sama sekali, berbicara tanpa tekanan emosi dan mempertahankan ekspresi wajah yang tidak bergerak (King,2007).

\section{Gejala Kognitif}

Gejala-gejala kognitif dari skizofrenia, meliputi kesulitan untuk mempertahankan atensi, hambatan dalam menyimpan informasi dalam ingatan dan ketidakmampuan untuk memaknai informasi dan membuat keputusan.Gejala-gejala kognitif ini mungkin tampak kecil dan sering kali hanya dapat dideteksi melalui tes-tes neuropsikologis. Individu yang mengalami skizofrenia ditandai dengan tiga gejala yang umum dialami,yaitu gejala positif,gejala negative dan gejala kognitif

\section{METODE PENEL.ITIAN}

Penelitian ini menggunakan metode penelitian kualitatif. Penelitian kualitatif merupakan suatu pendekatan terhadap suatu fenomena dalam situasi dimana fenomena tersebut ada yang berorientasi pada penemuan (Moleong, 2007). Penelitian kualitatif tidak memaksakan diri hanya

Mai Darni1Fakultas Psikologi Universitas Muhammadiyah Lampung. Email: umizanki@gmail.com

Sulastri2Fakultas Psikologi Universitas Muhammadiyah Lampung. Email: sulastri2270@gmail.com 
untuk membatasi penelitian pada upaya menerima atau menolak dugaan-dugaan, melainkan mencoba memahami situasi sesuai dengan bagaimana situasi tersebut tampak (Purwandari, 2009). Dalam penelitian ini menggunakan dua Teknik triangulasi yaitu triangulasi metode dan triangulasi data.Triangulasi metode dilakukan dengan beberapa metode yang digunakan peneliti dalam penelitian yaitu wawancara, observasi dan dokumentasi.Pada triangulasi data penulis menggunakan berbagai sumber dari hasil, observasi dan dokumentasi dan wawancara lebih dari satu subjek yang dianggap memiliki sudut pandang yang berbeda.

\section{HASIL}

\section{Responden Pertama (S)}

Dari teori mengenai kecemasan di atas terlihat pada kedua responden ini.Pada responden pertama selama mendampingi putrinya sakit kurang lebih tujuh tahun telah cukup melakukan perawatan secara medis.Setidaknya telah empat kali putrinya menjalani perawatan di RSJ.Responden yang hanya seorang ibu rumah tangga berusaha mencarikesembuhan bagi putrinya.Kondisi putri responden yang sakit membuat kecemasan pada responden, terutama saat terjadi kekambuhan.Saat ini kondisi putri responden berangsur membaik, hal ini bisa terlihat dari kemampuan putri responden yang telah melakukan kegiatan sehari-hari dengan berjualan dan mengikuti kursus menjahit. Beberapa kecemasan yang terjadi yaitu:

1) Kecemasan Pendidikan.

Putri responden mengalami gangguan skizofrenia saat berusia 14 tahun dan sedang duduk di bangku sekolah menengah pertama.Akibat sakit yang dialami putri responden membuatnya tidak bisa melanjutkan pendidikannya.Kondisi putri responden yang terputus masa pendidikannya membuat kecemasan pada responden. Terputusnya pendidikan putri responden membuat responden mengkhawatirkan masa depan putrinya.

\section{2) Kecemasan Masa Depan}

Kecemasan akan masa depan dirasakan dalam mendampingi putrinya. Selain kecemasan akan masa depan, kecemasan yang dialami responden bisa terlihat pada gangguan fisiologis. Hal ini terlihat dari hasil observasi dan wawancara penulis. Transkrip percakapan responden dan penulis memperlihatkan kecemasan responden:

Saya lebih kuatirin anak saya ini dari pada bapaknya, kalau dia ini (putrinya) masih panjang perjalannya, kalau bapaknya yaaa....namanya udah umur juga ,gak gitu saya kuatirin lah...,anak-anak yang lain juga bantuin saya (A147-A151SKM12)

Responden sering merasa khawatir dan takut akan masa depan putrinya selain itu, responden juga merasakan gangguan pada fisiknya, seperti pada percakapan berikut:

Kalau dulu pertama anak saya sakit, sering suka susah tidur, darah tinggi saya bu....sekarang saya udah pasrah memang ini nasib saya, jadi biar saya enggak sakit juga"(A161-A164 SKM14).

Kalau dulu pertama anak saya sakit, sering suka susah tidur, darah tinggi saya, Bu..sekarang saya sudah pasrah memang ini nasib saya, jadi biar saya enggak sakit juga...S161-S164

Hal ini diperkuat dengan transkrip percakapan dengan responden, sebagai berikut:

Alhamdulillah...semangat kursus jahitnya, dia kumpulin sendiri uang dari jualan, trus buat bayar kursusnya ini. (A138EK12)

Senang saya bu...mudah-mudahan bisa untuk bekal dia nanti (A143A144EK14)

Semuanya dukung dia bu.., apalagi kakak-kakaknya yang di padang. Kakaknya seneng bener bu...kan mereka kerja nyablon, tapi dulunya gak diajarin jahit sama bapaknya, jadi agak nyesel juga gak bisa jahit. Sekarang lihat adiknya bisa jahit, seneng bener bu.... (A139-A142 EK13)

Berkaitan dengan harapan responden terhadap putrinya mengenai kesembuhan, memiliki jodoh dan masa depan yang baik. Seperti terdapat dalam transkrip percapan berikut:

Harapan saya biar dia sembuh, bisa punya jodoh(S85S86EK7)

3) Kecemasan Tambahan

Responden saat ini tinggal bersama ketiga putrinya, kedua putrinya yang lain sedang menempuh pendidikan di sekolah menengah pertama dan

Mai Darni1Fakultas Psikologi Universitas Muhammadiyah Lampung. Email: umizanki@gmail.com

Sulastri2Fakultas Psikologi Universitas Muhammadiyah Lampung. Email: sulastri2270@gmail.com 
sekolah dasar. Saat putri responden mengalami kekambuhan hal lain yang menjadi kecemasannya adalah kedua putrinya. Hal ini dikarenakan saat putrinya kambuh maka kedua putrinya yang akan ketakutan karena tak jarang saat kambuh putrinya akan merusak barang yang ada di rumah dan memarahi adik-adiknya. Oleh karena itu responden berusaha untuk menjaga kedua putrinya dari rasa takut saat putrinya kambuh.

4) Dinamika psikologis responden I (S) Responden telah mendampingi putrinya yang mengalami gangguan skizofrenia kurang lebih tujuh tahun lamanya. Saat itu usia putrinya 14 tahun dan sedang duduk dibangku sekolah menengah pertama. Sejak saat itu pengobatan secara medis telah dilakukan demi kesembuhan putrinya.Akibat sakit yang dialami putrinya membuatnya harus berhenti sekolah.Menghadapi kondisi demikian membuat responden merasa khawatir akan masa depan putrinya. Responden merupakan ibu rumah tangga yang hanya mengurusi keenam anaknya di rumah.Saat ini ketiga anak responden telah berkeluarga.Tiga orang putrinya tinggal bersama responden dan suaminya. Melihat kondisi putrinya yang berangsur membaik, responden memilih berjualan di depan rumahnya untuk memenuhi kebutuhan hidup sehari-hari. Beberapa hal yang menjadi sumber kecemasan pada responden adalah, masa depan putrinya, kondisi sakitnya, pendidikan dan ada kecemasan tambahan.

Kecemasan tambahan yang dirasakan responden karena responden memiliki dua anak perempuan yang masih sekolah di SMP dan SD yang keduanya merupakan adik dari putrinya yang mengalami skizofrenia.Kecemasan itu manakala putrinya mengalami kekambuhan bisa membuat kedua putrinya ini ketakutan, dan responden harus segera mengkondisikan keduanya agar tidak ketakutan.Saat ini kondisi putri responden berangsur membaik, hal ini bisa terlihat dari kemampuan putri responden menjalankan aktivitas sehari-hari dan mengikuti kursus menjahit. Membaiknya kondisi putrinya membuat perasaan responden merasa senang dan memiliki harapan yang besar terhadap masa depan putrinya. Harapan responden diantaranya kesembuhan putrinya dan putrinya bisa mendapatkan jodoh.

\section{Responden Kedua ( $\mathbf{R})$}

1) Kecemasan karena sakit

Pada responden kedua $(R)$ masih sangat terlihat kecemasannya dalam menghadapi kondisi putrinya yang mengalami gangguan skizofrenia hampir tiga tahun ini.Kecemasan yang di rasakan responden berkaitan dengan sakit putrinya, pendidikan dan masa depannya.Hal ini diperkuat dengan hasil observasi, responden sering meremas-remas jari jemarinya, tampak curiga pada setiap awal pertemuan.Responden juga keberatan untuk memberikan foto atau di foto. Transkrip percakapan yang menunjukkan kecemasan responden adalah sebagai berikut:

"saya kadang suka susah tidur, lemes, gak semangat, jantungnya suka deg-degan. Gimana nantinya dia ini" (R90-R94 SKS SKM)

2) Kecemasan pendidikan

Putri responden walaupun saat ini kondisnya belum stabil, namun kegiatan sekolahnya tetap berjalan seperti biasa.Keluarga besar memberikan dukungan kepada putrinya untuk terus bersekolah.Namun untuk kegiatan diluar sekolah, responden membatasinya.Alasan responden membatasi kegiatan putrinya adalah karena kondisinya sendiri yang masih sangat mengkhawatirkan responden. Seperti dalam transkrip percakapan berikut:

sekolahnya ya lancer gak lancer bu.. namanya juga anak kayak gitu, gak bisa mikir yang berat-berat. Gurunya juga sudah kita kasih tau".tapi kalau tementemannya enggak tau. Kadang dia bilang nanti pingin kuliah, saya semangatin aja. lya...nanti dikuliahin,mau pilih apa (R75-R81 SKS SKP)

3) Kecemasan masa depan

Melihat kondisi putrinya yang seperti itu membuat responden mengkhawatirkan masa depan putrinya. Walaupun putrinya masih dapat melanjutkan pendidikannya, tetapi itu belum membuat responden memiliki harapan terhadap masa depannya.Hal ini ditambah lagi dengan belum terlihatnya potensi yang dapat membantunya saat dewasa kelak.Berdasarkan teori kecemasan diatas dan mengenai tingkatan kecemasan pada responden ada pada tingkatan kecemasan sedang.Dimana responden masih terlihat sering putus asa menghadapi kondisi yang harus di hadapinya.

Mai Darni'Fakultas Psikologi Universitas Muhammadiyah Lampung. Email: umizanki@gmail.com

Sulastri2Fakultas Psikologi Universitas Muhammadiyah Lampung. Email: sulastri2270@gmail.com 
Melihat kondisi putrinya yang belum stabil, responden tetap memiliki harapan yang cukup besar terhadap putrinya. Harapan itu berupa kesembuhan putrinya dan masa depan yang baik. Seperti terdapat pada transkrip percakapan berikut:

Dia bisa sembuh, bisa kerja untuk masa depan nyalah...(R47EK4)

\section{4) Dinamika Psikologis Responden $2(R)$}

Responden merupakan seorang orang tua tunggal setelah beberapa tahun lalu bercerai dari suaminya.Putrinya sendiri telah tiga tahun mengalami gangguan skizofrenia.Saat ini responden dan putrinya tinnggal bersama keluarga adiknya.Kehidupan mereka sangat tergantung dengan keluarga adiknya, untuk itu responden menjadi tukang cuci di rumah adiknya.Saat ini putri responden masih menempuh pendidikan di Sekolah Menengah Kejuruan.Kondisi putrinya yang belum membaik membuat responden terlihat sangat khawatir.Kecemasan yang di terjadi pada responden berdasarkan teori dari Nevid, Rathus, \& Greene (2005) menunjukkan tingkat sedang.Beberapa faktor yang menyebabkan kecemasan yang dirasakan responden diantaranya responden yang merupakan orang tua tunggal dan kondisi putrinya yang belum stabil. Sehingga membuat responden sangat mengkhawatirkan kelanjutan masa depan putrinya.

\section{DISKUSI}

Hasil penelitian sesuai dengan ciri-ciri kecemasan yang diungkapkan oleh Nevid, Rathus,\& Green (2003),yaitu:

1. Secara fisik meliputi kegelisahan, kegugupan, tangan dan anggota tubuh yang bergetar atau gemetar, banyak berkeringat, mulut atau kerongkongan terasa kering, sulit berbicara, sulit bernafas, jantung berdebar keras atau berdetak kencang, pusing,merasa lemas atau mati rasa,sering buang air kecil, merasa sensitif, atau mudah marah.

2. Secara behavioral meliputi perilaku menghindar, perilaku melekat dan dependent, perilaku terguncang.

3. Secara kognitif meliputi khawatir tentang sesuatu, perasaan terganggu atau ketakutan atau aphensi terhadap sesuatu yang terjadi dimasa depan, keyakinan bahwa sesuatu yang mengerikan akan segera terjadi tanpa penjelasan yang jelas, ketakutan akan kehilangan kontrol, ketakutan akan ketidakmampuan untuk mengatasi masalah, berpikir bahwa semuanya tidak bisa lagi dikendalikan, merasa sulit memfokuskan pikiran dan berkonsentrasi. Kecemasan sangat berkaitan dengan perasaan yang tidak pasti dan tidak berdaya. Keadaan emosi ini tidak memiliki objek yang jelas.Terkadang, seseorang menghadapi kecemasan sebagai sebuah tantangan sehingga mempersiapkan sesuatu untuk menghadapinya. Hal ini yang akan memberikan hasil yang positif. Tetapi terkadang pula, kecemasan membuat seseorang tidak berdaya, dan merasa tidak mampu menghadapi kecemasan itu sehingga ingin lari dari masalahnya dengan mengembangkan defend mechanism (mechanism pertahanan diri/ego

Melihat kecemasan yang dialami oleh responden dan di sesuaikan dengan tingkat kecemasan menurut Nevid, Rathus, \& Green(2005), maka tingkat kecemasan yang responden saat ini ada pada tingkatan kecemasan ringan.Kecemasan ringan berhubungan dengan ketegangan akan peristiwa kehidupan sehari-hari. Pada tingkat ini lahan persepsi melebar dan individu akan berhati-hati dan waspada. Individu terdorong untuk belajar yang akan menghasilkan pertumbuhan dan kreativitas.

a. Respon Fisiologis terdiri dari, sesekali nafas pendek, nadi dan tekanan darah naik, gejala ringan pada lambung, muka berkerut dan bibir bergetar.

b. Respon kognitif terdiri dari mampu menerima rangsangan yang kompleks, konsentrasi pada masalah, menyelesaikan masalah secara efektif.

c. Respon perilaku dan emosi terdiri dari tidak dapat duduk tenang, tremor halus pada tangan, suara kadang-kadang meninggi.

Pada responden pertama (S) kecemasan yang dirasakannya berangsur menurun seiring dengan kondisi putrinya yang mulai terlihat stabil. Hal ini bisa disebabkan karena beberapa faktor:

1) Rentang waktu hampir tujuh tahun dalam mendampingi putrinya ternyata cukup membuat responden mampu beradaptasi dengan keadaan yang harus dihadapi terutama mengelola kecemasan.

5) Dukungan yang cukup dari keluarga untuk kesembuhan dan kelanjutan masa depan putri responden

6) Putri responden mulai menunjukkan kemampuannya yang sangat menunjang masa depannya. Kemampuan yang dimiliki putri responden adalah menjahit dan berjualan. Tentu saja ini akan membantu keuangan dirinya dan keluarga responden.

Mai Darni1Fakultas Psikologi Universitas Muhammadiyah Lampung. Email: umizanki@gmail.com

Sulastri2Fakultas Psikologi Universitas Muhammadiyah Lampung. Email: sulastri2270@gmail.com 
Pada responden pertama $(R)$ kecemasan belum mengalami penurunan disebabkan beberapa faktor yaitu:

a. Responden adalah orang tua tunggal setelah bercerai dengan suaminya beberapa tahun yang lalu.

b. Responden sangat bergantung dengan keluarga adiknya dalam hal keuangan dan pengobatan putrinya.

c. Hampir tiga tahun putrinya mengalami gangguan skizofrenia, kondisi putrinya masih sangat labil.

d. Putri responden merupakan anak satu-satunya, yang seharusnya bisa menjadi tumpuan harapan bagi responden.

Responden pertama S dengan lamanya waktu mendampingi putrinya yang mengalami gangguan skizofrenia cukup mampu mengelola kecemasannya.Harapan responden terhadap kesembuhan putrinya cukup tinggi, yang didasari kondisi putrinya yang berangsur stabil dan mampu melakukan kegiatan sosial dan cukup mandiri secara finansial. Akan tetapi, muncul kecemasan lain yang dirasakan responden yaitu harus mengkondisikan keluarga terutama kedua anak yang kecil dan kondisi suamiyang mulai menunjukkan adanya gangguan skizofrenia. Kecemasan yang responden $S$ rasakan saat ini berada pada tingkat kecemasan ringan.Kondisi ini bisa disebabkan karena masa responden merawat putrinya selama kurang lebih tujuh tahun dan terlihat kondisi putri responden yang berangsur membaik.Putri responden telah mampu melakukan aktivitas sehari-hari, sehingga memunculkan harapan pada responden dengan kondisi yang dirinya dan putrinya alami.Harapanharapan tersebut berupa kesembuhan putriya dan memiliki pasangan hidup.

Pada responden kedua $\mathrm{R}$ yang masa mendamping putrinya yang mengalami gangguan skizofrenia hampir tiga tahun masih terlihat kecemasan dan kadang terlihat putus asa.Hal ini bisa disebabkan karena responden adalah orang tua tunggal dan putrinya merupakan anak satusatunya.Saat ini kondisi putrinya masih sangat labil, walaupun pendidikan masih terus dilanjutkan. Responden belum bisa melihat kemampuan yang dimiliki putrinya untuk membantunya mandiri di masa depan. Dukungan dari keluarga adik sangat membantu responden mengahadapi permasalahan yang dihadapi.
Cattel (Alwisol, 2009) menekankan pentingnya kecemasan sebagai aspek kepribadian karena bahaya dampaknya terhadap fungsi fisik dan mental. Menurutnya kecemasan itu bisa merupakan sutu keadaan sekaligus sifat dari kepribadian. Orang tertentu dapat mengalami berbgai tingkat kecemasan sebagai dampak keadaan yang mengancam atau menekan. Orang tersebut dalam keadaan cemas. Di sisi lain, ada orang yang terus menerus kronis cemas, yang berarti cemas itu menjadi bagian atau faktor dari kepribadiannya

\section{SIMPULAN DAN SARAN}

Ibu yang memiliki anak penderita skizofrenia ditemukan mengalami kecemasan. Ibu S mengalami tingkat kecemasan ringan, dikarenakan waktu mendampingi anak kurang lebih 7 tahun, sehingga masuk dalam tingkat kecemasan ringan yang membuat cukup mampu mengelola kecemasannya. Dan mempunyai harapan terhadap kesembuhan putrinya, dengan dasar kondisi putrinya yang berangsur-angsur stabil dan cukup mampu melakukan kegiatan sosial dan secara mandiri, sehingga resonden mempunyai akan kesembuhan total dari putri serta memperoleh pasangan hidup. Akan tetapi muncul kecemasan lain yang dirasakan yaitu harus mengkondisikan keluarga terutama kedua anak yang kecil dan kondisi suami yang mulai menunjukkan adanya gangguan skizofrenia.

Pada Responden kedua R. Masa mendampingi putri selama hampir tiga tahun. Masih sangat terlihat kecemasan dan kadang terlihat putus asa. Hal ini disebabkan karena responden adalah orang tua tunggal dan putrinya merupakan anak satu-satunya. Saat ini kondiri putri masih sangat labil, walapun demikian keadaanya tetapi pendidikan masih terus dilanjutkan. Selain itu, responden belum pernah melihat kemandirian pada putrinya. Responden masih memerlukan dukungan dari keluarga, terutama adik yang sangat membantu menghadapi masalah ini.

Bagi keluarga yang memiliki anggota keluarga dengan skizofrenia diharapkan memberikan dukungan penuh kepada penderita. Hal ini akan sangat membantu penderita skizofrenia. Peran orang tua dalam mendampingi remaja putri yang mengalami gangguan skizofrenia sangatlah dibutuhkan. Dukungan yang baik dari keluarga tentu saja berdampak positif bagi penderita skizofrenia. Lebih lanjut, lingkungan masyarakat cukup berperan bagi

Mai Darni1Fakultas Psikologi Universitas Muhammadiyah Lampung. Email: umizanki@gmail.com

Sulastri2Fakultas Psikologi Universitas Muhammadiyah Lampung. Email: sulastri2270@gmail.com 
terciptanya masyarakat yang sehat, oleh karena itu masyarakat juga dituntut untuk memberikan dukungan kepada penderita skizofrenia.Masyarakat diharapkan memberi ruang bagi penderita skizofrenia yang sudah cukup stabil untuk dapat terlibat dalam masyarakat. Sehingga diharapkan kondisi mereka yang mengalami gangguan skizofrenia akan berangsur membaik.

Sekolah dan guru juga diharapkan lebih berperan dalam mendampingi para remaja yang tengah menempuh pendididkan. Lebih menggiatkan lagi ruang konsultasi bagi para siswa yang memasuki usia remaja. Tidak bisa dipungkiri usia remaja dengan problematikanya membuat remaja membutuhkan ruang bagi mereka untuk mengungkapkan apa yang menjadi permasalahan mereka.

\section{DAFTAR PUSTAKA}

Alwisol (2009). Psikologi Kepribadian, Edisi Revisi. Malang, UMM Press

Asrori, M., \& Ali, M. (2006). Psikologi remaja perkembangan peserta didik. Jakarta: PT Bumi Aksara.

Hurlock, E. B. (2008). Perkembangan Anak Jilid 2 Edisi Ke-6. Jakarta: Erlangga.

Nevid, J. S., Rathus, S. A., \& Greene, B. (2005). Psikologi abnormal. Jakarta: Erlangga

Kaplan,H.I dan Sadock,B.J (1997). Sinopsis Psikiatri. Jakarta. Gramedia Widya Sarana

Kartono, K. (2010). Patologi Sosial 2 Kenakalan remaja. Jakarta: PT Raja Grafindo Persada.

Kartono, K. (2011). Patologi Sosial 3, Ganguangangguan kejiwaan. Jakarta: PT Raja Grafindo Persada

Laura A.King (2010). Psikologi Umum: Sebuah Pandangan Apresiatif. Jakarta Salemba Humanika.
Maslim, R. (2013). Rangkuman Diagnosis Gangguan Jiwa. Rujukan Ringkas dari PPDGJIII dan DSM-5. Jakarta: Bagian IImu Kedokteran Jiwa FK-Unika Atmajaya.

Moleong, L. J. (2007). Metodologi Penelitian Kualitatif: Bandung: Rosdakarya

Nefid Jeftey S, Ratus Spencer A dan Greene Beverly (2003) . Pengantar Psikologi Abnormal . Bandung, Erlangga

Notosoedirjo dan Latipun.2005. Kesehatan Mental Konsep dan Penerapan. Malang: UMM Press

Poerwandari (2009). Pendekatan Kualitatif Dalam Penelitian Psikologi. Jakarta Lembaga Pengembangan Sara Pengukuran dan Pendidikan Psikologi Fakultas Psikologi Universitas Indonesia

Sadock.B.J and Saddock, V.A (2001) Pocekt Handbook of Clinical psychiatry. Edisi ke 3. Philadelpia. Lippincott Williams \& Walkins.

Sarwono, S. W. (2010). Psikologi Remaja edisi revisi. Jakarta: PT. Raja Grafindo Persada

Setiadi. 2014. Pemulihan Gangguan Jiwa: Pedoman Bagi Penderita, keluarga dan Relawan. Tidak Dipublikasikan

Siswanto, (2007). Kesehatan Mental:K onsep, Cakupan dan Perkembangannya .Yogyakarta: C.V ANDI OFFSET

Sarwono, S. W. (2012). Psikologi Remaja edisi revisi. Jakarta: PT. Raja Grafindo Persada.

Kaplan, H. I., \& Sadock, B. J. (1990). Pocket handbook of clinical psychiatry. In Pocket handbook of clinical psychiatry.

Wiramihardja, S. A. (2005). Pengantar psikologi abnormal. Bandung: Refika Aditama.

Wiramihardja, (2015). Pengantar psikologi abnormal. Bandung: Refika Adita

Mai Darni1Fakultas Psikologi Universitas Muhammadiyah Lampung. Email: umizanki@gmail.com Sulastri²Fakultas Psikologi Universitas Muhammadiyah Lampung. Email: sulastri2270@gmail.com 